\title{
The Phytoextraction of Copper from Tropical Soil 21 Years after Amendment with Heavy-Metal Containing Waste
}

\author{
Gianluigi Silva, Septi Nurul Aini, Henrie Buchari and Abdul Kadir Salam \\ Department of Soil Science Faculty of Agriculture, University of Lampung \\ Bandar Lampung, Indonesia, e-mail :axauam@gmail.com \\ Received August 05, 2020; Revised December 17, 2020; Accepted 08 January 2021
}

\begin{abstract}
Several particular plants are suggested to extract significant parts of heavy metals from soils and accumulate them in their roots and shoots. This research aimed to study the phytoextraction of $\mathrm{Cu}$ by several plants from heavymetal contaminated tropical soils. Soil samples collected from plots treated in 1998 with 0,15 and $60 \mathrm{Mg}$ industrial waste $\mathrm{ha}^{-1}$ were planted with three different plants, i.e., caisim, water spinach, and lettuce. Plant parts (roots and shoots) and soil samples were harvested after a four-week growth period and analyzed for plant and soil $\mathrm{Cu}$. The results show that the growth of plants was depressed by the increase in the soil $\mathrm{Cu}$ (extracted by $1 \mathrm{~N} \mathrm{HNO}_{3}$ ) as affected by waste levels, with water spinach being the most progressive and produced the most significant biomass. The absorption of $\mathrm{Cu}$ by caisim and water spinach increased with the soil extracted $\mathrm{Cu}\left(\right.$ linear $\mathrm{R}^{2}=0.71 *$ for caisim and $0.32 *$ for water spinach) and accumulated greater in plant roots than that in shoots. The translocation factor $(\mathrm{TF}<<1.00)$ indicates that all plants were good $\mathrm{Cu}$ phytostabilizators rather than phytoextractors, with water spinach being the best $\mathrm{Cu}$ extractor.
\end{abstract}

Keywords: Copper, heavy metals, phytoextraction, phytoremediation, phytostabilization, pollution, translocation factor

\section{INTRODUCTION}

Heavy metals in soils are in general found at low levels that are not toxic to plants, animals, and humans. Heavy metals can be harmful when their concentrations are relatively high, exceeding the allowable limits for living things (Moenir 2010). The increasing concentration of heavy metals is usually caused by pollution of land around mining, industry, and modern agriculture (Priyanto and Prayitno 2006). The soil pollution may increase the heavy metal content over time (Salam 2017). As suggested by soil researchers, the accumulation of heavy metals in the soil environment can lead to a decrease in the soil microbial population and activity, the soil fertility, and the overall soil quality, and decrease the plant yield as well as cause the inclusion of the toxic materials into the food chains (Atafar et al. 2010). Heavy metals may also cause metabolic disorders for humans, depending on which heavy metals are bonded in the human body. The toxic power is to inhibit enzyme work impairing the body's

J Trop Soils, Vol. 26, No. 1, 2021: 11-18

ISSN 0852-257X; E-ISSN 2086-6682 metabolic processes (Chen and Ahsan 2004). All these conditions may jeopardize the living things and, therefore, must be appropriately managed.

There are several ways to overcome the problem of soils being polluted by heavy metals, one of which uses metalophyte plants to extract the heavy metals from soils. All plants can absorb heavy metals but in varying quantities. Several plants from many families are shown to have hipertolerant characteristics on heavy metals. Hypertolerant is capable of accumulating high concentrations of heavy metals in the root and shoot tissues and, thereby, called hyperaccumulator. Some of these plants may include amaranth, sunflowers, cabbage, chickpea, willows, broccoli, lettuce, and spinach, and several weeds like elephant grass (Ishii et al. 2015; Mallmann et al. 2014; Matthews-Amune and Kakulu 2012; Ng et al. 2016)

The process of eliminating, moving, or destroying heavy metal contaminants in soil, water, and underground water using particular plants or microorganisms is called bioremediation. Thebioremediation process using heavy metal bioaccumulation plants is called phytoremediation (Kambhampati and Williams 2001). The 
phytoremediation method uses plants to extract, neutralize, accumulate, and reduce contaminants from the soil, water, or air (Gerhardt et al. 2017) and is an effective and economical strategy for transporting heavy metals from soils (Nascimento et al. 2014; Sarwar et al. 2017). Phytoremediation is helpful to reduce the risks associated with heavy metal contaminants through the use of hyperaccumulator plants (Pinho and Ladeiro 2012). The plant species used in phytoremediation should have rapid growth potential, and free of diseases and pests, must be able to compete with less desirable species, must be able to adapt to local soils and climatic conditions, and also must be able to grow in infertile soils (Ranjan et al. 2015).

Therefore, it is crucial to explore the phytoremediation plants or phytoaccumulator plants. Phytoaccumulator plants are plants that can absorb significant amounts of heavy metals (hyperaccumulator). It is well understood that research exploring hyperaccumulator plants to clean heavy metal contaminated soils needs basic research on phytoextraction. Phytoextraction refers to the retrieval of heavy metal contaminants from soils by the roots of plants and their translocation to the harvested parts of the plant. Phytoextractor plants show the capability of removing heavy metals from soils (Bhargava et al. 2012). There is a great deal of research dealing with phytoextraction but limited for tropical plants or tropical soils. This research was to study the phytoextracting characteristics of several plants in tropical soils 21 years after contaminated with a Cu-containing industrial waste.

\section{MATERIALS AND METHODS}

\section{Experimental Set-Up}

This experiment was conducted in a plastic house of the College of Al-Madani in Bandar Lampung, Indonesia. Soil samples were collected from field plots set up in 1998 located in Sidosari Natar South Lampung Indonesia $\left(5^{\circ} 20^{\prime} 14.1^{\prime \prime S}\right.$ $105^{\circ} 14^{\prime} 39.2^{\prime \prime E}$ ) (Figure 1) (Salam and Ginanjar 2018). Soil samples were taken compositely from plots treated with only industrial waste at control level $\left(0 \mathrm{Mg} \mathrm{ha}^{-1}\right)$, low level $\left(15 \mathrm{Mg} \mathrm{ha}^{-1}\right)$, and high level $\left(60 \mathrm{Mg} \mathrm{ha}^{-1}\right)$. The soil sampling was conducted using an auger from $0-15 \mathrm{~cm}$. The soil samples were air-dried, sieved to $2 \mathrm{~mm}$, and mixed thoroughly before being used in this experiment.

A $200 \mathrm{~g}$ of soil sample $\left(105^{\circ} \mathrm{C}, 24\right.$ hours ovendry equivalent) was used as a planting medium. Plants including caisim (Brassica chinensis var. Parachinensis), water spinach (Ipomoea

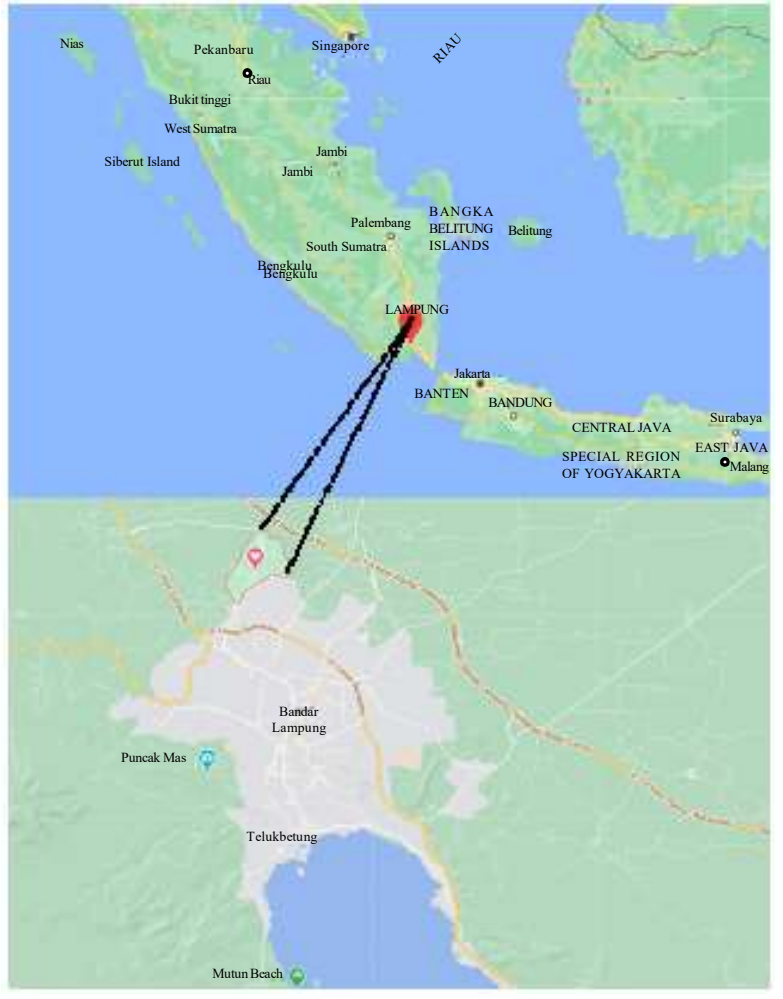

Figure 1. The google location of the experimental plots set up in 1998.

aquatica), and lettuce (Lactuca sativa) were planted in the soils after the addition of water to $40 \%$ (soil field-water capacity). Plants were allowed to grow for four weeks at the soil field-water capacity regulated by capillary water from a common water reservoir beneath the planting medium. All experimental units were replicated three times.

\section{Analysis of $\mathbf{C u}$}

At the end of the planting period, plant shoots and roots were harvested separately and weighed for wet weight and oven-dry weight $\left(60^{\circ} \mathrm{C}, 3 \times 24\right.$ hours), and analyzed for plant $\mathrm{Cu}$. The soil samples were also taken for $\mathrm{Cu}$ analysis using $1 \mathrm{~N} \mathrm{HNO}_{3}$ involving the iCE 3000 Atomic Absorption Spectrophotometer (AAS).

For analyzing plant $\mathrm{Cu}, 1 \mathrm{~g}$ of oven-dried and ground plant tissue was put in a porcelain crucible and placed in a furnace, heated at $300{ }^{\circ} \mathrm{C}$ for 2 hours and then at $500{ }^{\circ} \mathrm{C}$ for 4 hours, after which the plant sample was let to reach room temperature. The plant sample was wetted with several drops of distilled water and treated with $10 \mathrm{~mL}$ of $1 \mathrm{~N}$ $\mathrm{HCl}$ and put on a hot plate to boil gently. After cooling, the soluble plant tissue ash was filtered into a 100 $\mathrm{ml}$ volumetric flask. The crucible was then rinsed with $10 \mathrm{~mL} 1 \mathrm{NHCL}$ and about $50 \mathrm{~mL}$ distilled water on the filter paper into the volumetric flask. Distilled 

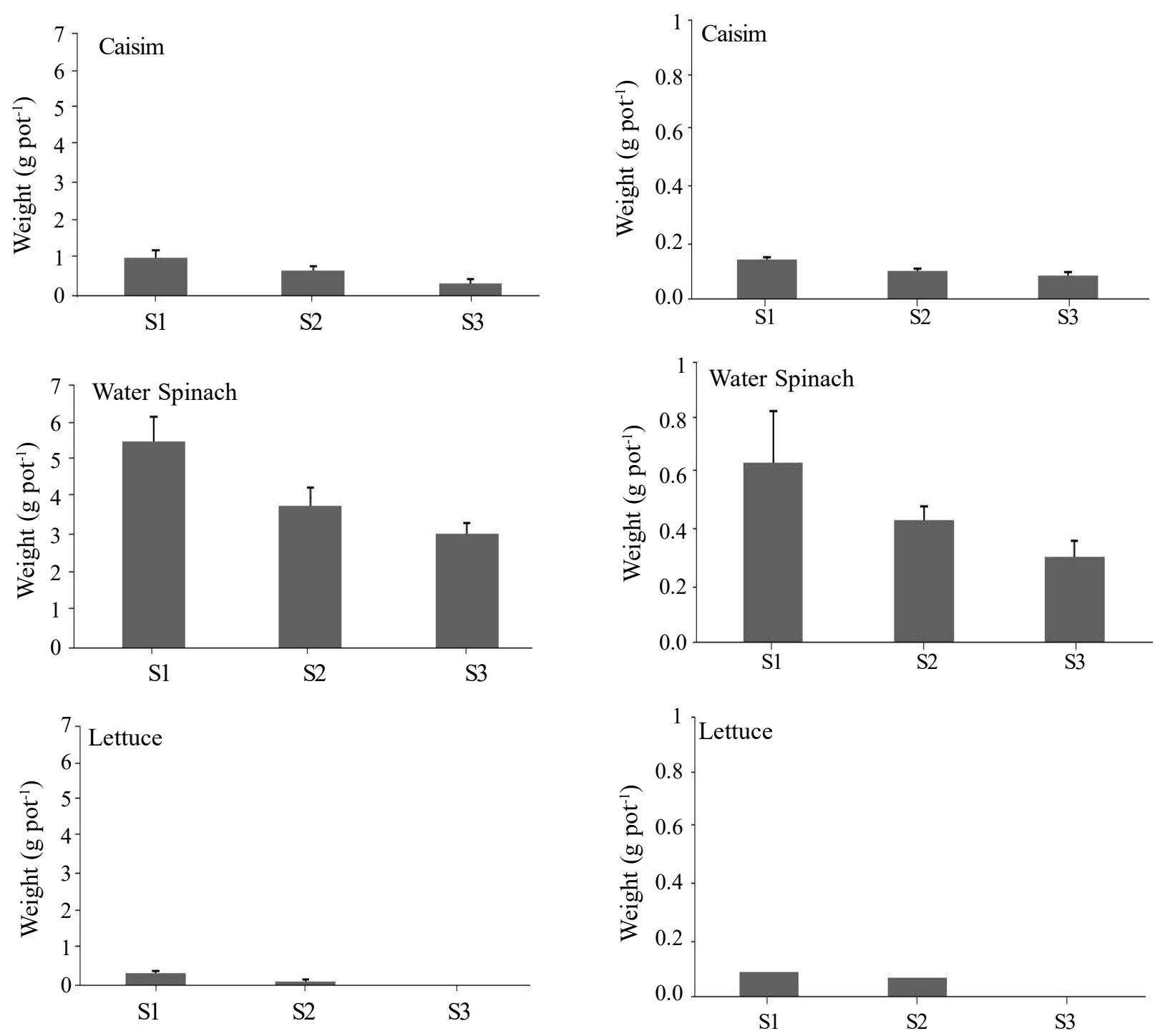

Figure 2. The wet weight of several plants planted in soils contaminated with heavy metals $\left(\mathrm{S}_{1}=\right.$ control, $\mathrm{S}_{2}=$ low heavy metals, $\mathrm{S}_{3}=$ high heavy metals; lettuce dead in $\mathrm{S}_{3}$ ).

water was added to dilute the filtrate to $100 \mathrm{~mL}$. The filtrate was gently shaken before analyzed using flame AAS at $\lambda=324.7 \mathrm{~nm}$.

For analyzing soil $\mathrm{Cu}, 2 \mathrm{~g}\left(105^{\circ} \mathrm{C}, 24\right.$ hours ovendry equivalent) of soil sample was put into an extracting bottle and $20 \mathrm{ml} 1 \mathrm{~N} \mathrm{HNO}_{3}$ was added. The mixture was then put in an end-to-end shaker for 2 hours. After filtration, the supernatant was then determined for $\mathrm{Cu}$ concentration using flame AAS at $\lambda=324.7 \mathrm{~nm}$ (Salam 2017).

\section{RESULTS AND DISCUSSION}

\section{The Growth of Plants}

The growth of plants is depicted in Figure 2 (wet weight), Figure 3 (dry weight), and Figure 4

Figure 3. The dry weight of several plants planted in soils contaminated with heavy metals $\left(\mathrm{S}_{1}=\right.$ control, $\mathrm{S}_{2}=$ low heavy metals, $\mathrm{S}_{3}=$ high heavy metals; lettuce dead in $\mathrm{S}_{3}$ ).

(plant height). The dry weight of plants was, in general, about 0.20 times the wet weight. Both wet weight and dry weight of plants decreased with the increase in heavy-metal-containing waste levels. For example, the dry weight of caisim in the control plot was $0.14 \mathrm{~g} \mathrm{pot}^{-1}$, and that in the highest waste level plot was $0.09 \mathrm{~g} \mathrm{pot}^{-1}$, decreased by $38.1 \%$. It was also observed in water spinach and lettuce, which decreased by $52 \%$ and $100 \%$, respectively. The dry weight of lettuce was $0 \mathrm{~g} \mathrm{pot}^{-1}$ in soil with the highest waste level (Figure 3). The uptake analysis of $\mathrm{Cu}$ shows that water spinach had the highest ability to absorb $\mathrm{Cu}$, followed by caisim and lettuce (Figure 5). However, in soils with high heavy metal content, the lettuce died. All these phenomena correspond to Samudro and Mangkoedihardjo (2010) statement that heavy metals at particular 

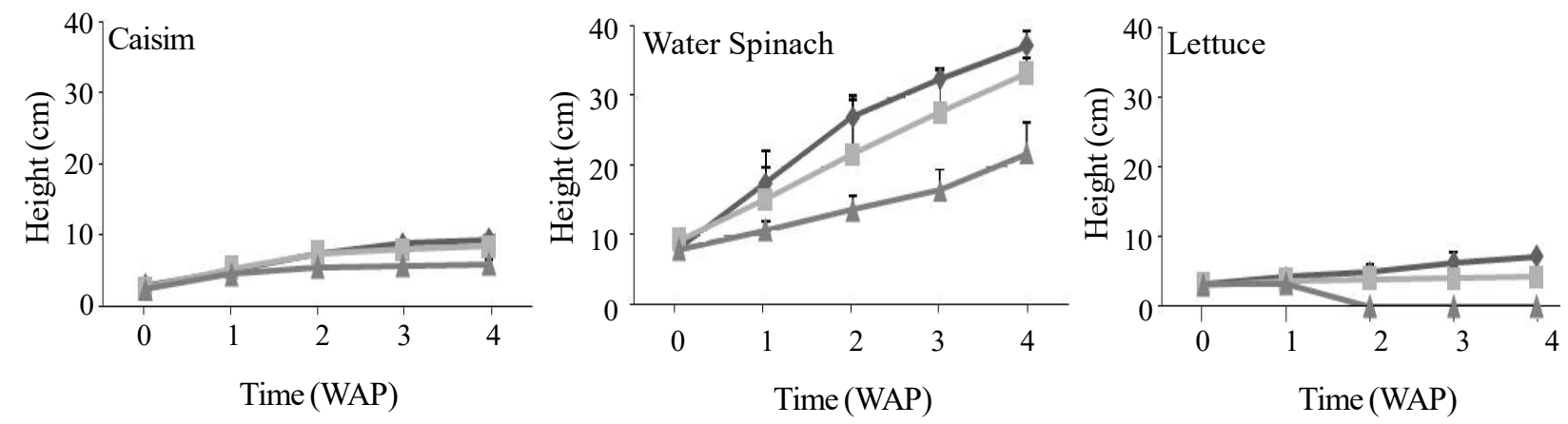

Figure 4 . The growth of several plants in heavy-metal contaminated soils $\left(\_-S_{1}=\right.$ control, $--S_{2}=$ low heavy metals, $\longrightarrow \mathrm{S}_{3}=$ high heavy metals; lettuce dead in $\mathrm{S}_{3}$ ).

quantities may accelerate plant growth, but at a high level, they may inhibit plant growth and may even cause death. Several soil workers also report similar phenomena (Salam 2017).

In addition to biomass, other parameters are also important in affecting the growth of plants, of which is the Root-To-Shoot Ratio (RSR). The RSR describes the comparison of plant ability in absorbing water and nutrients with the transpiration and the area of photosynthesis of plants (Lewenussa 2009), mathematically calculated by dividing the dry weight of root with shoot masses. Excellent and average plant growth is indicated by a balanced RSR that indicates that the roots and shoots of plants will be sturdy and not easy to collapse because the rooting system is capable of supporting the inadequate growth (Wibisono 2009). The RSR after harvesting for all treatment ranges from $0.30-0.50$ (Table 1) that indicates that, in general, most of the plant mass was distributed to the root parts of plants.

Table 1 clearly shows that the RSR values in general increase with the increase in $\mathrm{Cu}$ in waste. For example, the RSR of water spinach grown in the control soil was 0.40 , while that in the highest $\mathrm{Cu}$ containing waste was 0.50 . The presence of $\mathrm{Cu}$ in soils may have stimulated plant mass distribution

Table 1. The Root-To-Shoot Ratio (RSR) ${ }^{1}$ of several plants as affected by heavy-metal containing waste.

\begin{tabular}{lccc}
\hline \multirow{2}{*}{ Plants } & \multicolumn{3}{c}{ Waste Treatment } \\
\cline { 2 - 4 } & 0 & \multicolumn{1}{c}{15} & 60 \\
\hline \multirow{2}{*}{ Casino } & $\ldots \ldots \ldots \ldots$ & $\mathrm{Mg} \mathrm{ha}^{-1}$ & $\ldots \ldots \ldots \ldots$ \\
Water Spinach & 0.40 & 0.42 & 0.50 \\
Lettuce & 0.50 & 0.33 & 0.38 \\
\hline
\end{tabular}

${ }^{1} \mathrm{RSR}=$ dry mass of roots/dry mass of shoots; ${ }^{2} \mathrm{nd}=$ not determined; lettuce dead in $\mathrm{S}_{3} ; \mathrm{S}_{3}=$ high heavy-metal soils to the roots, which was typical for plant roots in responding to environmental stresses. This phenomenon was also previously reported for Napier grass (Pennisetum purpureum) grown in these soils (Hidayatullah 2020).

All the above data show that water spinach could grow well in the $\mathrm{Cu}$ polluted soils (Figure 2, Figure 3, and Figure 4). This plant is reported to have high adaptation power to environmental pressure such as heavy metals, as it is evident from its adaptability to contaminated soils and shows no toxicity symptoms (Haryanti et al. 2011). This plant also shows an anatomical adaptation to its survival in particular habitats (Haryanti et al. 2011). According to Mukhopadhyay and Maiti (2010), plants with high biomass and rapid growth, such as water spinach, tend to have better absorption and metal translocation. Conversely, the observation shows that lettuce experienced the symptoms of heavy metal toxicity in the form of chlorosis after four days of planting and then died two weeks after planting in soil treated with $60 \mathrm{Mg}$ waste ha ${ }^{-1}$. It is suggested that lettuce is not suitable for phytoremediation agents in soils with high heavy metals as the biomasses of all plants, the soil organic matter contents, and total $\mathrm{N}$ were also affected by heavy-metal-containing waste treatment. The soil organic matter content and total N (data not shown) decreased with heavy metal-containing waste (Silva 2020). One of the possibilities causing this phenomenon is that the presence of more heavy metal in soils may have depressed the ability of plant roots to produce organic exudates such as organic acids.

\section{The Cu Uptake by Plants}

Copper absorption by plants is presented in Figure 5 , and its relationship with the soil $\mathrm{Cu}$ concentrations is depicted in Figure 6. The absorption of $\mathrm{Cu}$ increased with the increase in the concentration of heavy metals in soils with relatively high linear $\mathrm{R}^{2}$ (Figure 6). Caisim and water spinach survived and absorbed higher heavy metals at the highest waste 

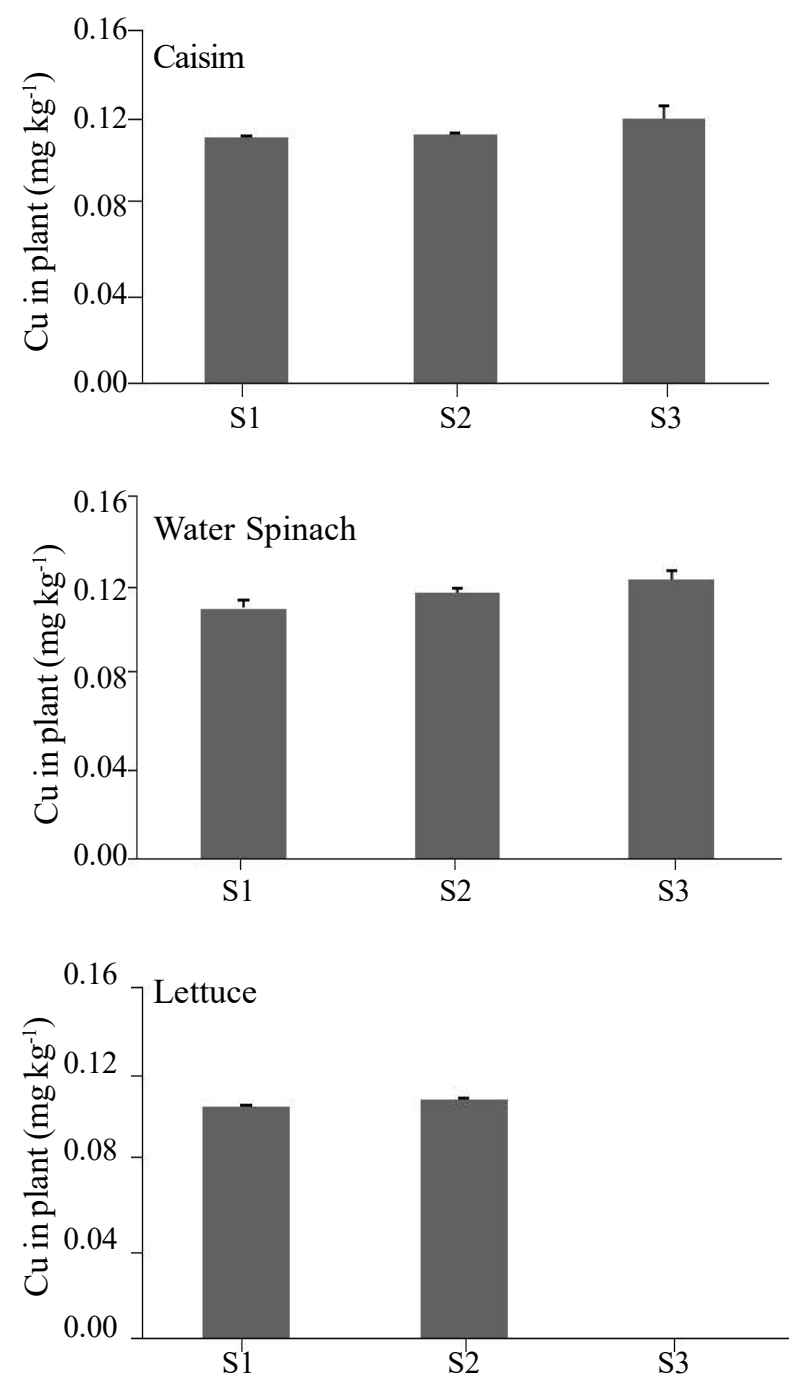

Figure 5. The absorption of $\mathrm{Cu}$ by several plants from $\mathrm{Cu}$-contaminated soils $\left(\mathrm{S}_{1}=\right.$ control, $\mathrm{S}_{2}=$ low heavy metals, $\mathrm{S}_{3}=$ high heavy metals; lettuce dead in $\mathrm{S}_{3}$ ).

of $60 \mathrm{Mg} \mathrm{ha}^{-1}$. However, lettuce was not adaptive to and dead at high heavy metal content in soils. According to Dahlan (2004), plant root is to absorb nutrients from soils and is in a direct contact with the planting medium, and absorb nutrients. The roots of the water spinach and caisim had large end and base parts. The roots of these plants also had smooth branches that spread throughout the planting medium, and therefore water spinach and caisim were able to absorb more $\mathrm{Cu}$. In contrast, lettuce had a small rooting volume and tended to accumulate small amounts of heavy metals. Another factor that caused the death of lettuce was the high soil heavymetal content. Gerth (2000) stated that the response of plants to metals also occurred in limiting the growth of roots and shoots and decreasing the rate of transpiration. The hyperaccumulator plant shows a different response compared to a standard plant

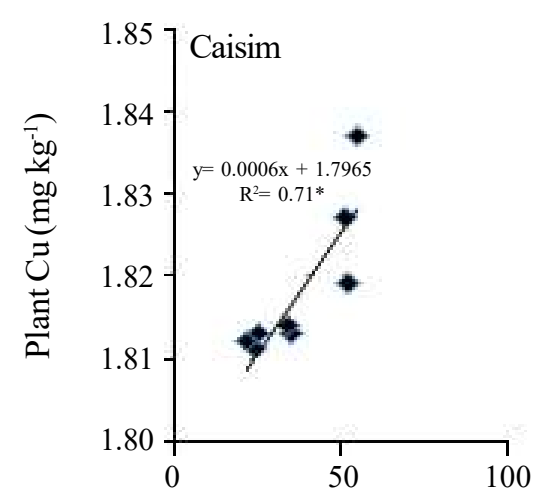

Soil $\mathrm{Cu}\left(\mathrm{mg} \mathrm{kg}^{-1}\right)$

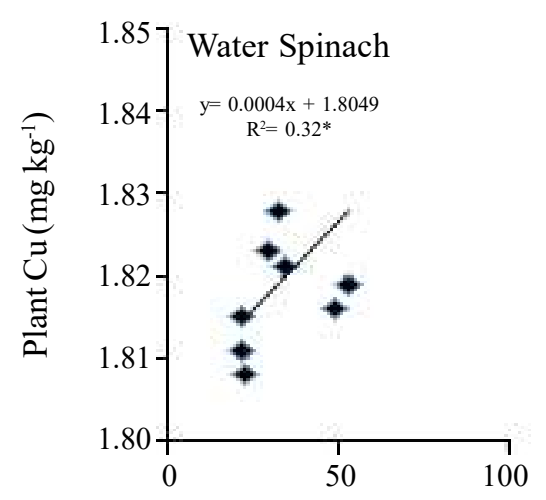

Soil $\mathrm{Cu}\left(\mathrm{mg} \mathrm{kg}^{-1}\right)$

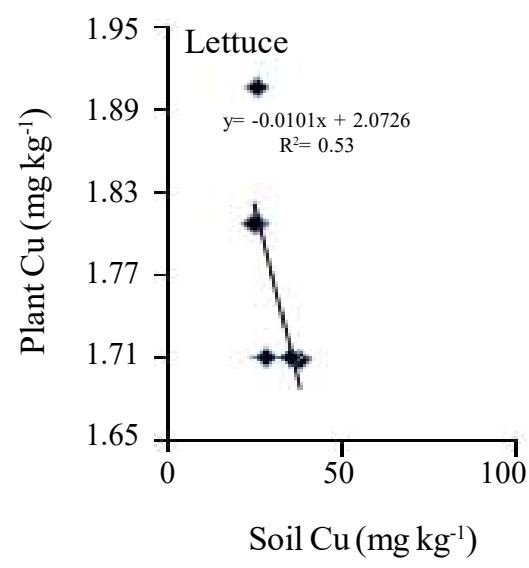

Figure 6. The relationship between plant $\mathrm{Cu}$ and soil $\mathrm{Cu}$ in heavy-metal contaminated soils (no uptake data in $\mathrm{S}_{3}$; lettuce dead in $\mathrm{S}_{3}$; $\mathrm{S}_{3}=$ high heavy-metal soils).

against the stress of metal poisoning. Figure 5 shows that all plants could accumulate metals with different concentrations in plant tissues, but the lettuce was unable to survive in the soil with high heavy metal content. Water spinach accumulated the highest $\mathrm{Cu}$, followed by caisim and then lettuce.

According to Mukhopadhyay and Maiti (2010), plants with high biomass and rapid growth tended to have high heavy metal absorption and better metal translocation. The highest absorption of $\mathrm{Cu}$ showed these characteristics by water spinach. To prevent 
Table 2. The root and shoot concentrations and translocation factor of $\mathrm{Cu}$ in several plants grown in heavy metal contaminated soils.

\begin{tabular}{|c|c|c|c|c|c|c|c|c|c|}
\hline \multirow{3}{*}{ Plants } & \multicolumn{9}{|c|}{ Waste Treatment } \\
\hline & \multicolumn{3}{|c|}{$0 \mathrm{Mg} \mathrm{ha}^{-1}$} & \multicolumn{3}{|c|}{$15 \mathrm{Mg} \mathrm{ha}^{-1}$} & \multicolumn{3}{|c|}{$60 \mathrm{Mg} \mathrm{ha}^{-1}$} \\
\hline & Root & Shoots & $\mathrm{TF}^{1}$ & Root & Shoots & $\mathrm{TF}$ & Root & Shoots & $\mathrm{TF}$ \\
\hline & \multicolumn{2}{|c|}{$\ldots \quad \mathrm{mg} \mathrm{kg}^{-1} \quad \ldots}$. & & \multicolumn{2}{|c|}{$\ldots \quad \mathrm{mg} \mathrm{kg}^{-1} \quad \ldots$} & & \multicolumn{2}{|c|}{$\ldots \quad \mathrm{mg} \mathrm{kg}^{-1} \quad \ldots$} & \\
\hline Caisim & 0.32 & 0.06 & 0.19 & 0.32 & 0.06 & 0.19 & 0.32 & 0.06 & 0.19 \\
\hline $\begin{array}{l}\text { Water } \\
\text { Spinach }\end{array}$ & 0.30 & 0.05 & 0.17 & 0.33 & 0.06 & 0.18 & 0.33 & 0.06 & 0.18 \\
\hline Lettuce & 0.32 & 0.05 & 0.16 & 0.32 & 0.05 & 0.16 & $\mathrm{nd}^{2}$ & nd & nd \\
\hline
\end{tabular}

${ }^{1} \mathrm{TF}$ Translocation factor $=\mathrm{Cu}$ in shoots/Cu in roots; ${ }^{2} \mathrm{nd}=$ not determined; lettuce dead in $\mathrm{S}_{3} ; \mathrm{S}_{3}=$ high heavy-metal soils

metal poisoning of cells and tissues, particular plants also have a detoxification mechanism, for example, by stockpiling metals in particular organs such as roots (Priyanto and Prayitno 2006). In the root tissues, heavy metals may enter the cortex and are accumulated near the endoderm. Endoderm has functioned as a barrier to heavy metal removal from roots (Siswanto 2009). Therefore, the accumulation of heavy metals is, in general, more significant in roots than in shoots. This phenomenon is observed for $\mathrm{Cu}$ accumulation (Table 2), in which the accumulated $\mathrm{Cu}$ was more significant in plant roots than those in shoots. Data in Table 2 show that the $\mathrm{TF}$ values were all $<<1.00$, indicating that more $\mathrm{Cu}$ was accumulated in roots than in shoots.

In the process of phytoextraction, the heavy metals contained in soils are subsequently absorbed by roots and translocated to shoots. The accumulation of $\mathrm{Cu}$ by water spinach makes it possible as a phytoremediation agent in $\mathrm{Cu}$ contaminated soils through phytostabilization, in which greater $\mathrm{Cu}$ is accumulated in roots. It is in line with Huang et al. (2017), stating that plant roots have a role more important than plant shoots in restoring contaminated soils. However, the selection of plants for phytoremediation does not consider only the ability of the plant to absorb heavy metals but also the growth response of plants. Khan et al. (2000) explain that to optimize the success of phytoremediation, and the selected plants must be fast-growing, have a high ability to absorb metals, and provide large biomass.

\section{The Changes in Soil $\mathrm{Cu}$ by Plants}

The contents of $\mathrm{Cu}$ in soils before and after planting by these plants are given in Table 3 . The concentrations of $\mathrm{Cu}$ extracted by $1 \mathrm{NHNO}_{3}$ were in general lower after planting. The decline by caisim was $20.8 \%$, by water spinach was $23.7 \% \%$, and by lettuce was $19.1 \%$. These values indicate that these plants were good absorbers for $\mathrm{Cu}$ from soils. These data also indicate that water spinach could decrease the soil concentration of $\mathrm{Cu}$ more significantly from $\mathrm{Cu}$-contaminated soils.

\section{CONCLUSIONS}

The wet and dry weight and the growth of caisim, water spinach, and lettuce were depressed by the presence of high $\mathrm{Cu}$ in soils as affected by heavy-metal-containing waste. The growth and mass weights of water spinach were greater than those of caisim and lettuce. The Root-To-Shoot Ratio of the plant was increased by $\mathrm{Cu}$, indicating that $\mathrm{Cu}$ stimulated the growth of plant roots in response to the more toxic soil environment. The absorption of $\mathrm{Cu}$ increased with the increase in soil $\mathrm{Cu}$ with high linear $\mathrm{R}^{2}$ and accumulated in roots greater than that in shoots. The soil $\mathrm{HNO}_{3}$ - extracted $\mathrm{Cu}$ decreased significantly by planting.

Table 3. The changes in the $\mathrm{Cu}$ concentrations in heavy-metal contaminated soil as affected by several plants in soils polluted with heavy metals.

\begin{tabular}{|c|c|c|c|c|}
\hline Plants & $\begin{array}{l}\text { Before } \\
\text { Planting }\end{array}$ & $\begin{array}{c}\text { After } \\
\text { Planting }\end{array}$ & \multicolumn{2}{|c|}{ Difference } \\
\hline & ....... & $\mathrm{mg} \mathrm{kg}^{-1}$ & & $\ldots \ldots \%$ \\
\hline Casino & 46.5 & 36.8 & -9.7 & -20.8 \\
\hline Water Spinach & 46.5 & 35.5 & -11.0 & -23.7 \\
\hline Lettuce & 46.5 & 37.6 & -8.9 & -19.1 \\
\hline
\end{tabular}




\section{ACKNOWLEDGEMENTS}

Gratitude is extended to Suwarto, the former soil and plant analyst in the Laboratory of Soil Science of the University of Lampung, for the help in conducting the laboratory works. The funding by the Directorate General of Higher Education, the Ministry of National Education the Republic of Indonesia, particularly in the initial setting of the experimental plots through Competitive Research Grant in $1995-1999$, is appreciated.

\section{REFERENCES}

Atafar Z, A Mesdaghinia, J Nouri, M Homage, M Yunesian, M Ahmadimoghaddam and AH Mahvi. 2010. Effect of fertilizer application on soil heavy metal concentration. Environ Mon Assess 160:8389. https://doi.org/10.1007/s10661-008-0659-x

Bhargava A, FF Carmona, M Bhargava and S Srivastava. 2012. Approaches for enhanced phytoextraction of heavy metals. $J$ Environ Manage 105:103-120. https://doi.org/10.1016/j.jenvman.2012.04.002

Chen Y and H Ahsan. 2004. Cancer burden from arsenic in drinking water in Bangladesh. Am J Public Health 94: 741-744. https://doi.org/10.2105/AJPH.94.5.741

Dahlan EN. 2004. Membangun Kota Kebun (Garden City) Bernuansa Hutan Kota.IPB Press. Bogor. (in Indonesian).

Gerhardt KE, PD Gerwing and BM Greenberg. 2017. Opinion: Taking phytoremediation from proven technology to accepted practice. Plant Sci 256:170185. https://doi.org/10.1016/j.plantsci.2016.11.016

Gerth A. 2000. Phytoremediation of soil and sludge with special examination of heavy metal contamination. In: DL Wis (ed). Bioremediation of contaminated soils. Marcel Dekker, New York, pp. 787-809.

Haryanti S, RB Hastuti, ED Hastuti and Y Nurchayanti. 2011. Adaptasi morfologi fisiologi dan anatomi eceng gondok (Eichhornia crassipes (Mart) Solm) di berbagai perairan tercemar. Bull Anatomi Fis 14: 39-46. (in Indonesian). doi: https://doi.org/10.14710/ baf.v14i2.2576

Huang D, L Liu, G Zeng, P Xu, C Huang, L Deng, R Wang and J Wan. 2017. The effects of rice straw biochar on indigenous microbial community and enzyme activity in heavy metal-contaminated sediment. Chemosphere 174: 545-553. doi: https://doi.org/ 10.1016/j.chemosphere.2017.01.130

Hidayatullah A. 2020. Ketersediaan dan Serapan Cu dan Zn Rumput Gajah (Penissetum purpureum) pada Tanah 21 Tahun Setelah Tercemar Logam Berat dan Dikapur [skripsi]. Universitas Lampung. Bandar Lampung. (in Indonesian).

Ishii Y, K Hamano, D Kang, S Idota and A Nishiwaki. 2015. Cadmium phytoremediation potential of napiergrass cultivated in Kyushu, Japan. Appl Environ Soil Sci ID 756270. https://doi.org/10.1155/ 2015/756270
Kambhampati MS and L Williams. 2001. Phytoremediation of lead-contaminated soils using Mirabilis jalapa. Phytoremed Wetlands Sed, 145-150. https://doi.org/ 10.102/es9604828.

Khan AG, C Kuek, TM Chaudhry, CS Khoo and WJ Hayes. 2000. Role of plants, mycorrhizae, and phytochelatins in heavy metal contaminated land remediation. Chemosphere 41: 197-207. https:// doi.org/10.1016/S0045-6535(99)00412-9

Lewenussa A. 2009. Pengaruh mikoriza dan bioorganik terhadap pertumbuhan bibitCananga odorata (Lamk) Hook. Fet \& Thoms [skripsi]. IPB Bogor. (in Indonesian).

Mallmann, JFK, S Rheinheimer, CAlberto, C Cella, J Paolo and V Filipovi. 2014. Soil tillage reduces surface metal contamination - model development and simulations of zinc and copper concentration profiles in a pig slurry-amended soil. Agric Ecosyst Environ 196: 59-68. https://doi.org/10.1016/ j.agee.2014.06.024

Matthews-Amune OC and S Kakulu. 2012. Determination of heavy metals in forage grasses (Carpet Grass (Axonopus Ompressus), Guinea Grass (Panicum maximum), and Elephant Grass (Pennisetum Purpureum)) in the vicinity of Itakpe Iron Ore Mine, Nigeria, 13: 16-25.

Moenir M. 2010. Kajian fitoremidiasi sebagai alternatif pemulihan tanah tercemar logam berat. J Ris Teknol Pencegahan Pencemaran Industri 1: 115-123. (in Indonesian).

Mukhopadhyay S and SK Maiti. 2010. Phytoremediation of metal mine waste. Applied Eco Environ Res 8: 207-222.

Nascimento SS, EB Silva, LRF Alleoni, FG Fonseca and BO Nardis. 2014. Availability and accumulation of lead for forage grasses in contaminated soil. $J$ Soil Sci Plant Nutr 14: 783-802. doi: https://doi.org/ 10.4067/s0718-95162014005000063

$\mathrm{Ng} \mathrm{CC}$, MM Rahman, AN Boyce and R Abas. 2016. Heavy metals phyto-assessment is commonly grown vegetables: water spinach (I. Aquatica) and okra ( $A$. esculentus). Springer Plus 5. doi: https://doi.org/ 10.1186/s40064-016-2125-5

Pinho S and B Ladeiro. 2012. Phytotoxicity by lead as heavy metal focuses on oxidative stress. $J$ Botany ID369572. doi: https://doi.org/10.1155/2012/369572

Priyanto B and J Prayitno. 2006. Fitoremediasi sebagai Sebuah Teknologi Pemulihan. BPPT. (in Indonesian).

Ranjan V, P Sen, D Kumar and A Sarsawat. 2015. A review on dump slope stabilization by revegetation with reference to indigenous plant. Ecol Process 4. doi: https://doi.org/10.1186/s13717-015-0041-1

Salam AK. 2017. Management of Heavy Metals in Tropical Soil Environment. Global Madani Press. Bandar Lampung.

Salam AK and K Ginanjar. 2018. Tropical soil labile fractions of copper in the experimental plots \pm ten years after application of copper-containing-waste. J Trop Soils 23: 11-18. https://doi.org/10.5400/jts.2018.v23i1.11-18. 
Samudro G and S Mangkoedihardjo. 2010. Review on $\mathrm{BOD}, \mathrm{COD}$, and BOD/COD ratio: a triangle zone for toxic, biodegradable, and stable levels. Int J Ac Res 2: 235-239.

Silva G. 2020. Fitoekstraksi Cu dan Zn dari Tanah Tercemar Logam Berat oleh Beberapa Tanaman [skripsi]. Universitas Lampung. Bandar Lampung. (in Indonesian).

Sarwar N, M Imran, M, MR Shaheen, W Ishaque, MA Kamran, A Matloob, A Rehim and S Hussain. 2017. Phytoremediation strategies for soils contaminated with heavy metals: Modifications and future perspectives. Chemosphere 171: 710-721. https:// doi.org/10.1016/j.chemosphere.2016.12.116
Siswanto D. 2009. Respon Pertumbuhan Kayu Apu (Pistia stratiotes L.) Jagung (Zea mays L.) dan Kacang Tolo (Vigna sinensis L.) terhadap pencemaran Timbal $(\mathrm{Pb})$. Universitas Brawijaya. Malang.

Wibisono HS. 2009. Pemanfaatan mychorizal helper bacteria (MHBS) dan fungsi mikoriza arbuskula (FMA) untuk meningkatkan pertumbuhan semai gmelina (Gmelina arborea Roxb) [Skripsi]. Institut Pertanian Bogor. Bogor. (in Indonesian). 